\title{
INCIDENTAL CATCHES OF FRANCISCANA IN COASTAL GILLNET FISHERIES IN THE FRANCISCANA MANAGEMENT AREA III: PERIOD 1999-2000
}

\author{
Eduardo R. Secchi ${ }^{1,2}$, Paul G. Kinas ${ }^{3}$ and Monica Muelbert ${ }^{1}$
}

\begin{abstract}
Bycatch of franciscanas in fishing operations along the western South Atlantic Ocean has been observed for approximately 60 years. Reports on bycatch in shark gillnet fisheries off Uruguay date back to the early 1940s. A decade later, gillnet fisheries for bottom-dwelling fish became the major conservation concern for franciscanas in both Brazil and Argentina. A small portion (c. $10 \%$ ), of the coastal gillnet fleet which operate from the port of Rio Grande (southern Rio Grande do Sul, Brazil) was monitored in 1999-2000. The total annual bycatch was estimated to be 946 franciscanas (non-parametric CI = $467-1525$ ) for the year 1999 and 719 (non-parametric CI = CI: 248 - 1413) dolphins for 2000. The total bycatch for the whole FMA III was 1106 (CI: 578 - 1915) for 1999 and 992 (CI: 475 - 1832) for 2000. Since data were not normally distributed confidence intervals were estimated by non-parametric bootstrap. Despite strong evidence of decline for the stock from FMA III, no mitigation strategy has been established or designed. Instead, fishing effort is still very high, it is increasing and bycatch is uncontrolled. Thus, prompt management action is required. Regulation of gillnet fishing effort might be the only suitable immediate action to mitigate the bycatch.

Resumo - Capturas acidentais de toninhas em operações de pesca têm sido observadas por aproximadamente 60 anos ao longo de sua distribuição no Atlântico Sul-Ocidental. Em águas uruguaias, os registros de capturas nas redes de emalhe, usadas na pesca de tubarões, datam do início dos anos 40. Uma década mais tarde, a pescaria de peixes demersais com redes de emalhe tornou-se a principal preocupação em relação à conservação da espécie tanto no Brasil como na Argentina. Em 1999 e 2000, monitorou-se uma pequena parcela (c. 10\%) da frota costeira que opera com redes de emalhe na costa sul do Rio Grande do Sul, Brasil. Estimou-se uma captura acidental anual de 946 toninhas (I.C. não-paramétrico $=248$ - 1423) para o ano de 1999 e de 719 toninhas (I.C. não-paramétrico $=248-1423$ ) para o ano de 2000. A captura acidental anual para toda a FMA III (FMA: Área de Manejo para a Toninha) foi estimada em 1106 (I.C. = 578 - 1915) e 992 (I.C. $=475$ - 1832) toninhas em 1999 e 2000, respectivamente. Os intervalos de confiança foram estimados através de procedimentos de "bootstrap" não-paramétrico, visto que os dados não apresentavam distribuição normal. Até o presente, nenhuma estratégia mitigatória foi implementada ou elaborada, apesar das fortes evidências que o estoque da FMA III está declinando. Além disso, o esforço pesqueiro continua elevado, crescendo e as capturas acidentais sem controle. Ações de manejo pesqueiro são urgentemente necessárias. Talvez, a regulamentação do esforço de pesca seja a única atitude imediata aplicável e com chances de ser eficiente.
\end{abstract}

Keywords: Franciscana, bycatch, gillnet fisheries, western South Atlantic, conservation

\section{Introduction}

Mortality due to incidental entanglement in gillnets is by far the greatest threat to the franciscana (e.g. Ott et al., 2002; Secchi and Wang, 2002; Secchi et al., 2003b), and was first observed about sixty years ago in shark gillnet fisheries off Uruguay (Van Erp, 1969). Although gillneting in southern Brazil and Argentina emerged in the 1940s (Haimovici et al., 1997; E. Crespo, pers. commn), no record of bycatch exists for that time. Gillnet fisheries for bottom-dwelling fish became the major conservation concern for franciscana in Brazil and Argentina only in the 1980s and early 1990s, respectively, when dedicated research began. Recently, bycatch has been reported from all of the main fishing villages along the species' distribution (e.g. Corcuera, 1994; Cremer et al., 19954; Praderi, 1997; Secchi et al., 1997; Di Beneditto et al., 1998; Bertozzi and Zerbini, 2002; Ott et al., 2002; Rosas et al., 2002; Secchi et al., $2003 b$ ). However, the levels of bycatch vary greatly according to the geographical location, and seem to be higher in southern Brazil, Uruguay and Argentina (see Ott et al., 2002 and Secchi et al., $2003 b$ for a comprehensive review).

In Uruguay, Praderi (1997) estimated that between 1974 and 1994 at least 3,683 dolphins were killed. The highest and lowest annual estimates were 418 and 66 dolphins caught in 1974 and 1994, respectively. Bycatch was even higher prior to this period. In the late $1960 \mathrm{~s}$ the annual bycatch was estimated to be as high as 1,500 to 2,000 animals (Brownell and Ness, 1970; Pilleri, 1971).

Between 1976 and 1987, 1,085 franciscanas were found dead (Pinedo, 1994) along the coast of Rio Grande do Sul State, Brazil. Bycatch estimates from monitoring of gillnet fleets in the same area were appreciably higher, ranging from several hundred dolphins to more than a thousand per year (Secchi et al., 1997; Ott, 1998; Ott et al., 2002; Secchi et al., $2003 b$ ). There is evidence of high bycatch and population decline (e.g. Secchi, 1999; Kinas, 2002, Secchi and Wang, 2002) in southern Brazil. Therefore, one could expect the number of dolphin captures to decrease if the fishing effort remains stable or decreases. However, despite the collapse of some fish stocks, fishing effort is increasing and the number of franciscanas annually caught remains high.

In this article we estimate the total bycatch of franciscana in the coastal gillnet fishery off Rio Grande do Sul state (southern Brazil) and Uruguay, corresponding to Franciscana Management Area (herein FMA) III (see Secchi et al., 2003a) for the years 1999 and 2000. For modelling purposes (in Secchi and Fletcher, 2004) the bycatch estimates for the other FMAs were compiled from the literature (Table 1$)$.

\footnotetext{
${ }^{1}$ Marine Mammal Research Group, University of Otago, PO Box 56, Dunedin, New Zealand.

${ }^{2}$ Current address: Universidade do Rio Grande, Laboratório de Mamíferos Marinhos, Museu Oceanográfico “Prof. Eliézer C. Rios”. Cx.P. 379, Rio Grande, RS, 96200-970, Brazil.

${ }^{3}$ Fundação Universidade Federal do Rio Grande, Departamento de Matemática e Estatística. Cx.P. 477, Rio Grande, RS 96200-970 Brazil. ${ }^{4}$ Cremer, M.J., Brutto, L.F., Simões-Lopes, P.C. and Diefenbach, C.O. (1995) The catch of Pontoporia blainvillei in Santa Catarina state, southern Brazil. Page 26 in Abstracts XI Biennial Conference on the Biology of Marine Mammals. 14-18 December, Orlando, USA.
} 
Table 1. Summary of characteristics of the coastal fishery responsible for franciscana bycatch along the four Franciscana Management Areas. Values are approximations and the fishery characteristics are highly variable between fishing villages within a FMA. For FMA III estimates are for years 1999 and 2000.

\begin{tabular}{|c|c|c|c|}
\hline $\begin{array}{c}\text { MANAGEMENT } \\
\text { AREA }\end{array}$ & RANGE & GENERAL CHARACTERISTICS OF THE FISHERIES ${ }^{\bullet}$ & ANNUAL BY-CATCH* \\
\hline$\sum_{i}^{\lessgtr}$ & $\begin{array}{l}\text { Itaúnas }\left(18^{\circ} 25^{\prime} S\right) \text { to } \\
\text { Ubatuba }\left(23^{\circ} 18^{\prime} S\right), \\
\text { southeastern Brazil }\end{array}$ & $\begin{array}{l}\text { Fleet: about } 75 \text { boats } \\
\text { Gear: surface and bottom gillnets } \\
\text { Main target species: sciaenids and sharks } \\
\text { Net length: up to } 2,400 \mathrm{~m} \text { (most are smaller) } \\
\text { Net width: about } 5 \mathrm{~m} \\
\text { Mesh size: } 14 \mathrm{~cm} \\
\text { Depth: } 6 \text { to } 70 \mathrm{~m} \\
\text { Distance from the coast: } 1 \text { to up to } 60 \text { miles }\end{array}$ & $\begin{array}{l}\text { Minimum: } 44 \\
\text { Average: } 110 \\
\text { Maximum: } 176\end{array}$ \\
\hline$\sum_{i}^{\Xi}$ & $\begin{array}{l}\text { Ubatuba }\left(23^{\circ} 18^{\prime} S\right) \text {, } \\
\text { southeastern Brazil to Torres } \\
\left(29^{\circ} 19^{\prime} S\right), \quad \text { southern Brazil }\end{array}$ & $\begin{array}{l}\text { Fleet: about } 100 \text { boats } \\
\text { Gear: surface and bottom gillnets } \\
\text { Main target species: sciaenids, sharks, } \\
\text { mullet and flounders } \\
\text { Net length: from } 120 \mathrm{~m} \text { (artisanal fishery) } \\
\text { up to } 6,000 \mathrm{~m} \text { (commercial) } \\
\text { Net width: } 1.5 \text { to } 5 \mathrm{~m} \text { (bottom gillnets); } \\
7.5 \text { to } 12 \mathrm{~m} \text { (surface gillnets) } \\
\text { Mesh size: } 6 \text { to } 22 \mathrm{~cm} \\
\text { Depth: up to } 40 \mathrm{~m} \\
\text { Distance from the coast: up to } 60 \text { miles }\end{array}$ & $\begin{array}{l}\text { Minimum: } 63 \\
\text { Average: } 279 \\
\text { Maximum: } 497\end{array}$ \\
\hline$\underset{\Downarrow}{\Xi}$ & $\begin{array}{l}\text { Torres }\left(29^{\circ} 19^{\prime} S\right) \text {, southern } \\
\text { Brazil to the border between } \\
\text { Uruguay and Argentina, } \\
\text { about in the middle of the } \\
\text { La Plata river mouth } \\
\left(\sim 35^{\circ} 30^{\prime} S\right)\end{array}$ & $\begin{array}{l}\text { Fleet: about } 150 \text { boats } \\
\text { Gear: bottom and surface gillnets } \\
\text { Main target species: sciaenids, gadids and sharks } \\
\text { Net length: } 3,000 \text { up to } 11,000 \mathrm{~m} \text { (bottom gillnets); } \\
300 \text { to } 4,000 \mathrm{~m} \text { (surface gillnets) } \\
\text { Net width: } 2 \text { to } 4 \mathrm{~m} \text { (bottom gillnets); } 6 \text { to } 15 \mathrm{~m} \\
\text { (surface gillnets) } \\
\text { Mesh size: } 9 \text { to } 38 \mathrm{~cm} \\
\text { Depth: up to } 40 \mathrm{~m} \\
\text { Distance from the coast: } 1 \text { to up to } 60 \text { miles }\end{array}$ & $\begin{array}{l}\text { Minimum: } 356-694 \\
\text { Average: 1049-1374 } \\
\text { Maximum: 2033-2215 }\end{array}$ \\
\hline$\sum_{i}^{\gtrless}$ & $\begin{array}{l}\text { The border between } \\
\text { Uruguay and Argentina, } \\
\text { about in the middle of the } \\
\text { La Plata river mouth } \\
\left(\sim 35^{\circ} 30^{\prime} S\right) \text { to Golfo Nuevo } \\
\left(42^{\circ} 35^{\prime} S\right) \text {, Chubut, Argentina }\end{array}$ & $\begin{array}{l}\text { Fleet: } 110 \text { boats } \\
\text { Gear: } 52 \text { use gillnets and } 58 \text { shrimp trawl } \\
\text { Main target species: sciaenids, sharks } \\
\text { and shrimps } \\
\text { Net length: } 35 \text { to } 200 \text { (artisanal) and up to } 4,000 \\
\text { (commercial) fishery } \\
\text { Net width: } 1.2 \text { to } 2 \mathrm{~m} \text { (artisanal fishery); } 3 \text { to } 5 \mathrm{~m} \\
\text { (commercial fishery) } \\
\text { Mesh size: } 10 \text { to } 30 \mathrm{~cm} \\
\text { Depth: up to } 30 \mathrm{~m} \\
\text { Distance from the coast: up to } 30 \text { miles }\end{array}$ & $\begin{array}{l}\text { Minimum: } 241 \\
\text { Average: } 405 \\
\text { Maximum: } 567\end{array}$ \\
\hline
\end{tabular}

*The annual by-catches are rough estimates based on combined information from different studies within the range of each FMA. (•) *Source: Praderi et al., 1989; Corcuera, 1994; Corcuera et al., 1994; Pinedo, 1994; Siciliano, 1994; Cremer et al., 1995; Praderi, 1997; Secchi et al., 1997; Zanelato, 1997; Corcuera et al., 2000; Di Beneditto et al., 1998; Kinas and Secchi, 1998; 1999; Ott, 1998; Capozzo et al., 2000; Di Beneditto and Ramos, 2001a,b; Bertozzi and Zerbini, 2002; Rosas et al., 2002; Santos et al., 2002, Di Beneditto, 2003, and this study. 


\section{Methods}

During 1999 and 2000, 10 and 9 coastal gillnet boats respectively from Rio Grande (southern Rio Grande do Sul State) were monitored (Table 2). Although this is a small proportion of the fleet (c. 9 to $10 \%$ ), the monitored boats are representative for the whole fleet as they use the same fishing gear, target the same species and operate in the same fishing areas. Logbooks were provided to each of these boats with the aim of obtaining information on bycatch of franciscana, fishing location, effort and characteristics of the fishing gear. The fishers were asked to bring all franciscanas killed in their nets back to port. Visits to the fishing docks were conducted often, almost daily, to recover the carcasses. At the end of the first year logbooks were collected and replaced with new ones to be used during the next year. Capture per unit of effort (CPUE) was calculated separately for either of the two main target species: the white croaker (Micropogonias furnieri) and striped weakfish (Cynoscion guatucupa). CPUE was based on the number of dolphins entangled divided by the total effort (net size times number of settings) and expressed as the number of dolphins captured in 1000 linear metres of net per set (franciscana $x$ [1000 m net $]^{-1}$ ). For CPUE analysis, only those specimens caught in nets of the surveyed boats were considered [fishers from unsampled boats occasionally bring in franciscanas killed in their nets]. Uncertainty in CPUE estimates was calculated by non-parametric bootstrap (Manly, 1997). The data provided by each boat $i(i=1, \ldots, b)$ included: 1$)$ number of animals by-caught $\left(C_{i}\right) ; 2$ ) number of sets in the year $\left(S_{i}\right)$; 3) average length of net deployed during the season $\left(L_{i}\right)$ (see Table 2). For each year, bootstrap sampling of $b$ boats taken randomly with replacement was performed 10,000 times.

For each sample, total bycatch $(T c)$ was then estimated as CPUE times the mean total effort times the number of boats $(B)$ in the fleet (see equations 1 and 2).

$$
\begin{aligned}
& \text { (eq. 1) } T c=C P U E \times \frac{\sum S_{i} \times L_{i}}{b} \times B \\
& \text { (eq. 2) } \quad T c=C P U E \times\left(\frac{\sum S_{i}}{b} \times \frac{\sum L_{i}}{b}\right) \times B
\end{aligned}
$$

The difference between the two equations is related to the degree of covariance between the number of sets $S$ and the length of the nets $L$. The covariance is:

Table 2. Fishing effort and bycatch of franciscana in white croaker and stripped weakfish gillnet fisheries in southern Brazil. Information includes the number of settings $\left(S_{i}\right)$, mean net length $\left(L_{i}\right)$, mean total effort $\left(E_{i}\right)$ and total number of franciscanas caught $\left(C_{i}\right)$ by each boat

\begin{tabular}{|c|c|c|c|c|c|c|c|c|}
\hline YEAR/BOAT & $\begin{array}{c}S_{i} \\
\text { (FOR CROAKER) }\end{array}$ & $\begin{array}{c}S_{i} \\
\text { (FOR WEAKFISH) }\end{array}$ & $\begin{array}{c}L_{i} \\
\text { CROAKER (m) }\end{array}$ & $\begin{array}{c}L_{i} \\
\text { WEAKFISH (m) }\end{array}$ & $\begin{array}{c}E_{i} \\
\text { CROAKER (m) }\end{array}$ & $\begin{array}{c}E_{i} \\
\text { WEAKFISH (m) }\end{array}$ & $\begin{array}{c}C_{i} \\
\text { (CROAKER) }\end{array}$ & $\begin{array}{c}C_{i} \\
\text { (WEAKFIS }\end{array}$ \\
\hline \multicolumn{9}{|l|}{1999} \\
\hline 1 & 23 & 2 & 8244 & 6436 & 189612 & 12872 & 4 & 0 \\
\hline 2 & 18 & 4 & 12423 & 9348 & 223614 & 37392 & 6 & 6 \\
\hline 3 & 33 & 11 & 10648 & 7972 & 351384 & 87692 & 8 & 0 \\
\hline 4 & 36 & 3 & 12202 & 8045 & 439272 & 24135 & 24 & 0 \\
\hline 5 & 13 & 5 & 12389 & 7691 & 161057 & 38455 & 1 & 0 \\
\hline 6 & 21 & 7 & 10973 & 6436 & 230433 & 45052 & 4 & 0 \\
\hline 7 & 27 & 9 & 9891 & 10973 & 267057 & 98757 & 9 & 2 \\
\hline 8 & 13 & 0 & 6302 & 0 & 81926 & 0 & 1 & 0 \\
\hline 9 & 27 & 0 & 8045 & 0 & 217215 & 0 & 6 & 0 \\
\hline 10 & 17 & 0 & 10973 & 6436 & 186541 & 0 & 2 & 0 \\
\hline Total & 171 & 41 & 76770 & 56901 & 13127670 & 2332941 & 56 & 8 \\
\hline \multicolumn{9}{|l|}{2000} \\
\hline 1 & 12 & 12 & 13355 & 7884 & 160260 & 94608 & 4 & 4 \\
\hline 2 & 8 & 39 & 10136 & 6947 & 81088 & 270933 & 0 & 1 \\
\hline 3 & 46 & 28 & 9438 & 7550 & 434148 & 211400 & 19 & 5 \\
\hline 4 & 8 & 5 & 8742 & 8624 & 69936 & 43120 & 1 & 3 \\
\hline 5 & 10 & 76 & 9770 & 7870 & 97700 & 598120 & 0 & 0 \\
\hline 6 & 19 & 12 & 12829 & 8045 & 243751 & 96540 & 5 & 0 \\
\hline 7 & 27 & 45 & 10843 & 6585 & 292761 & 296325 & 2 & 4 \\
\hline 8 & 3 & 0 & 6757 & 0 & 20271 & 0 & 6 & 0 \\
\hline 9 & 12 & 3 & 8742 & 7080 & 104904 & 21240 & 4 & 1 \\
\hline Total & 130 & 217 & 75113 & 53505 & 9764690 & 11610585 & 31 & 17 \\
\hline
\end{tabular}
$i$. Italicised rows represent the boats for which information appeared incomplete. 


$$
\text { (eq. 3) } \operatorname{Cov}(S, L)=E\{S \times L\}-E\{S\} \times E\{L\}
$$

where $E\{\}$ represents the expected value. The method of moments estimator of $E\{S \times L\}$ and $E\{S\} \times E(L\}$ correspond to the term within brackets in equations 1 and 2, respectively. Now, if:

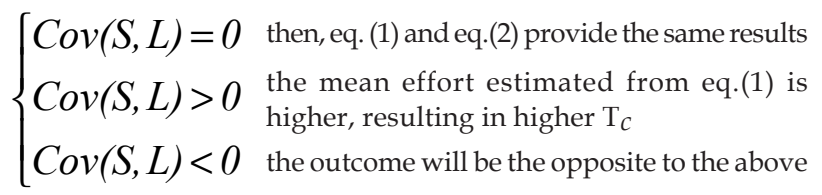

The confidence interval for Tc was estimated as the $2.5^{\text {th }}$ and $97.5^{\text {th }}$ percentiles of the bootstrap replicates (Manly, 1997).

This estimation approach assumes that franciscanas are equally vulnerable to any boat in the fleet. Because there is no current bycatch estimate from northern Rio Grande do Sul and Uruguay, it was assumed that the boats from these areas operate in the same fashion as in southern Rio Grande do Sul (i.e. the Rio Grande fleet). Total bycatch was extrapolated to a fleet of about B $=150$ boats (i.e. 105 from Rio Grande, 35 from northern Rio Grande do Sul and around 10 from Uruguay). Since the main target species are the same for those areas (see Ott et al., 2002; Secchi et al., 2003b), the assumption of similar fishing dynamics is reasonable. This extrapolation was made only for modelling purposes and is not meant as a substitute for empirical estimates of bycatch in each location.

Because some boat skippers completed the logbook only when franciscanas were caught in their nets or for a small part of the fishing season, the estimates of CPUE and total bycatch were based on data from boats with most complete records. This left seven boats as a basis for bycatch estimation. Because of the arbitrary nature of this approach, estimates based on all monitored boats are also provided for comparison.

\section{Results}

The CPUE was higher in 1999 [0.0294 (SD=0.0064) and $0.024(\mathrm{SD}=0.018)]$ than in 2000 [0.0212 $(\mathrm{SD}=0.0077)$ and $0.0119(\mathrm{SD}=0.0059)]$ for both white croaker and striped weakfish fisheries, respectively. However, these differences were not statistically significant $(\mathrm{p}>0.05)$.

The estimated total bycatch for southern Rio Grande do Sul are 946 (CI: 456 - 1530) for 1999 and 704 (CI: 250 1354) for 2000 (equation 1). Using equation 2, the bycatch estimates are 946 (CI: 467 - 1525) and 719 (CI: 248 - 1413), for 1999 and 2000, respectively. The total bycatch for the whole FMA III (Table 3) was 1374 (CI: 694 - 2215) for 1999 and 1049 (CI: 356 - 2033) for 2000 using equation 1. From equation 2, the estimate was 1106 (CI: 578 1915) for 1999 and 992 (CI: 475 - 1832). In both years the total estimated bycatch was high relative to population size ( $\sim 42,000$ animals; CI $\sim 32,000$ to 53,500$)$ provided by Secchi et al. (2001).

The distribution of the bycatch in FMA III for both years estimated from those boats with the most complete records is shown in Figure 1.

\section{Discussion}

The fishing fleet based out of Rio Grande is responsible for the largest portion of franciscana bycatch in southern Brazil and includes commercial, semi-commercial and artisanal fishing.

Table 3. Estimated annual bycatch of franciscanas in the coastal gillnet fleet operating from Rio Grande ( $\mathrm{n}=105$ boats), southern Rio Grande do Sul (Brazil). Values were obtained from equations 1 (first row of each block) and 2 (second row of each block). Estimates obtained when all monitored boats are considered are shown within brackets. The last row of each year shows the estimates for the three areas: Uruguay, southern and northern Rio Grande do Sul (fleet size $=150$ boats).

\begin{tabular}{|c|c|c|c|c|}
\hline YEAR & TARGET SPECIES & MEAN BYCATCH & SE & NON-PARAMETRIC $95 \%$ CI \\
\hline \multirow{7}{*}{ ळे } & \multirow{3}{*}{ Croaker } & $824(682)$ & $274(213)$ & 397 (346); 1427 (1155) \\
\hline & & $827(675)$ & $268(206)$ & 407 (348); 1406 (1134) \\
\hline & & $118(84)$ & $83(61)$ & $0(0) ; 294(210)$ \\
\hline & \multirow[t]{2}{*}{ Weakfish } & $115(66)$ & $82(52)$ & $0(0) ; 293$ (189) \\
\hline & & $946(764)$ & $279(222)$ & 456 (378); 1530 (1239) \\
\hline & \multirow[t]{2}{*}{ Total } & $946(739)$ & $274(216)$ & 467 (370); 1525 (1207) \\
\hline & & $1374(1106)$ & $383(346)$ & 694 (578); 2215 (1915) \\
\hline \multirow{7}{*}{ §ి } & \multirow{3}{*}{ Croaker } & $456(481)$ & $243(192)$ & 103 (187); 1001 (910) \\
\hline & & $464(469)$ & $256(195)$ & 99 (176); 1031 (912) \\
\hline & & $251(210)$ & $75(66)$ & 103 (82); 397 (338) \\
\hline & \multirow[t]{2}{*}{ Weakfish } & 259 (194) & $80(73)$ & 105 (63); 405 (345) \\
\hline & & $704(694)$ & $292(231)$ & 250 (327); 1354 (1202) \\
\hline & \multirow[t]{2}{*}{ Total } & $719(664)$ & $306(234)$ & 248 (319); 1413 (1190) \\
\hline & & 1049 (992) & $440(353)$ & 356 (475); 2033 (1832) \\
\hline
\end{tabular}


The results suggest that larger mesh size (i.e. nets set for croaker) might have a higher contribution to franciscana bycatch. Total bycatch in 1999 was higher than in 2000, which could have been due to higher effort for croaker. These nets are suspected to be more harmful to franciscana not only because of the larger mesh size $(14-16 \mathrm{~cm}$ in comparison to $9 \mathrm{~cm}$ stretched mesh for weakfish nets) but also because they generally operate in shallower waters which overlap with franciscana distribution to a greater extent (Dapper et al., in prep ${ }^{5}$ ). Assessment of the vulnerability of franciscana to different nets, areas and by season is a research priority currently under investigation (Dapper et al., in prep).

In Uruguay, large mesh nets targeting sharks were responsible for about 70 to $90 \%$ of the captures from the beginning of the gillnet fishery until the decline of the shark
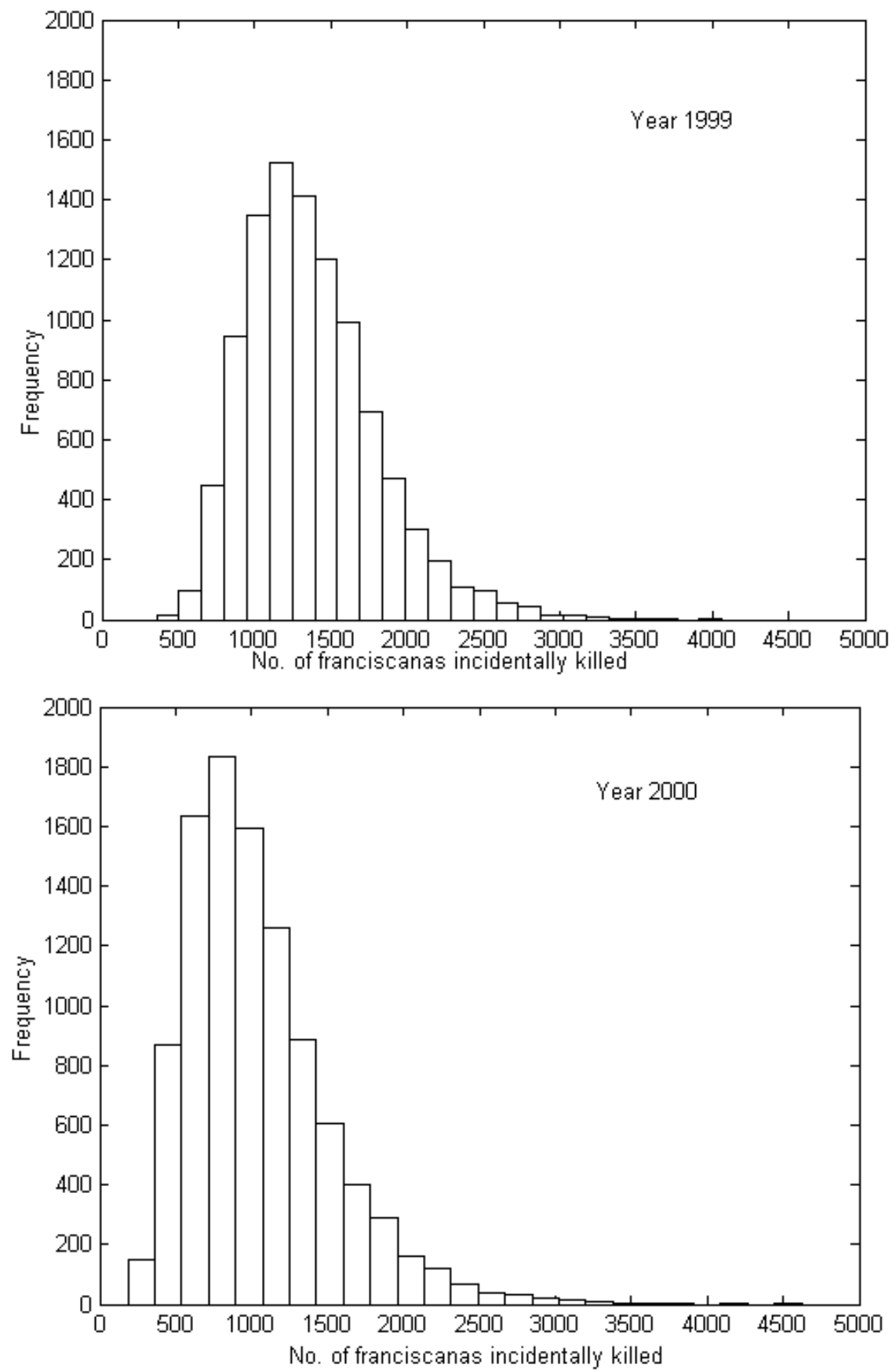

Figure 1 - Distribution of the bootstrap estimates of bycatch of franciscana in FMA III during years 1999 (top) and 2000 (bottom).

\footnotetext{
${ }^{5}$ Dapper, C., Secchi, E.R, Kinas, P.G. and Muelbert, M. (in prep) Seasonal, spatial and gear type vulnerability of franciscana dolphin in southern Brazil.
} 
fishery in the mid 1980s (e.g. Praderi, 1997; 2000). Depletion of the target shark species led to a drop in the fishing effort using large mesh $(32 \mathrm{~cm})$ nets (Praderi, 1997). Almost all the gillnet effort in the 1960s and 1970s employed large mesh nets. Today, most fishers use small $(10-12 \mathrm{~cm})$ but some use medium $(20-22 \mathrm{~cm})$ mesh nets. Such changes in the Uruguayan coastal fishery were believed to be beneficial to the recovery of the franciscana from the intense bycatch pressure of the past (Praderi, 1997). However, fishing effort using small mesh nets to catch teleost fish increased in the 1990s and the fishery was prosecuted closer to shore mainly in spring and summer when, according to Praderi (1997), franciscanas move inshore to prey upon shrimps (Artemesia longinaris). Although the use of large mesh nets is thought to be more harmful to the cetacean species off Uruguay, small mesh sized nets are responsible for all bycatch in southern Rio Grande do Sul. Therefore, if the overlap between gillnet fisheries (regardless of the mesh size of the nets) and franciscana increases in Uruguay, the bycatch pressure will not decrease as suspected by Praderi. It is worthwhile to note that there is a high rate of franscicana bycatch in adjacent areas of southern Brazil which alone is likely to offset or nullify any recovery expected for franciscanas from Uruguay. According to Praderi (2000), recent reported reductions in bycatch off Uruguay are, at least partly, due to underreporting. He stated that current records of incidental kill are less reliable than in the past because fishers fear enforcement of recent laws that protect franciscanas in Uruguay. On the other hand, bycatch off Rio Grande do Sul is still high, as reported a few years ago (Secchi et al., 1997; Kinas and Secchi, 1998; Ott, 1998). Secchi et al. (1997) had reported an annual bycatch of about 460 for the southern Rio Grande do Sul coast in 1994. However, this value was probably underestimated for at least two reasons: a) the study was in its infancy and fishers were not as cooperative as they are today; b) some boats included in the analysis of Secchi et al. (1997) started reporting bycatch only late in the season, resulting in a lower reported bycatch for these individual boats. The combination of these two factors may have affected the extrapolation of total bycatch for the whole fleet.

Due to a number of logistical constraints, only a small portion of the fishing fleet was monitored. Hence, there is wide variation in bycatch estimates. The industrial fleet usually operates beyond the offshore limit of franciscanas distribution. However, industrial boats sometimes fish closer to shore and hence pose a potential risk of bycatch. Secchi et al. (1997) reported that of a sample of 97 bycaught franciscanas, three had been caught by an industrial boat which had set a net near the $30 \mathrm{~m}$ isobath. Furthermore, small artisanal boats which make short (half day) trips to set nets very close to shore, were not monitored. These boats are known to catch franciscanas throughout the species' range (e.g. Bertozzi and Zerbini, 2002; Bordino et al., 2002; Rosas et al., 2002 - see also Ott et al., 2002 and Secchi et al., $2003 b$ for a review). "Active gillnets" 6 set for bluefish (Pomatomus saltatrix), are also known to catch franciscanas (see Secchi et al., 1997) and were also not included in the analysis because the number of boats targeting bluefish is unknown for the period of this study. In the Buenos Aires Province (Argentina), trawling for shrimps is responsible for relatively high franciscana bycatch (Cappozzo et al., 2000). Trawling effort for teleost fish is high in coastal waters off Rio Grande do Sul and can potentially catch franciscanas, though no bycatch has been reported so far. This might be due to lack of monitoring effort directed to this fleet.

An additional source of bias is that some bycaught franciscanas may have fallen from nets and not been seen by fishers. Similar "drop-outs" are reported for other areas by observers onboard gillnet fishing boats (e.g. Bravington and Bisack, 1996). It is also likely that the actual number of fishing boats for the fleet is underestimated because this was determined from direct counting of semi-commercial boats in situ. Some boats may not have been in the port during boat censuses. Secchi et al. (1997) reported that between 140 and 150 coastal (semi-commercial) boats operated from the port of Rio Grande, which included boats from two fishing communities. Despite the many uncertainties mentioned above, the evidence suggests that bycatch is underestimated, which is a general rule of bycatch estimates (Hall, 1999). Hence, the true bycatch is likely to be within the upper half of the statistical confidence interval. For management purpose it is recommended that downward bias in the bycatch estimates is acknowledged. The reason for being conservative is not only due to the scientific evidence that bycatch is underestimated, but also because precaution is crucial when management action is already delayed.

\section{Recommendations}

The levels of franciscana bycatch in the FMA III is high. Any change in mesh size (e.g. to smaller mesh to catch teleost fish in Uruguay) would be unlikely to reduce bycatch substantially if overlap between franciscana and nets is high. Perhaps the most immediate action to reduce bycatch is by limiting fishing effort in terms of maximum allowable net length and number of boats via law enforcement. Compliance could easily be verified by inspection in the port. Restricting fishing grounds (e.g. time and/or local closures), although potentially effective, would rely on the fishers' willingness to co-operate. Hence, education programs need to be implemented in parallel.

Despite the lack of franciscana bycatch records in trawling operations, other harmful effects of this fishery cannot be

\footnotetext{
${ }^{6}$ These 'run-around' gillnets (locally called cerco) are used only in winter. The fishers search for schooling bluefish and, after finding them they run the net around the school. However, unlike purse seining, the bottom of the nets is not closed after entrapping the fish and thus it operates as a gillnet.
} 
overlooked. Trawling destroys benthic communities and results in bycatch of large amount of juvenile sciaenid fish. These fish are the main components of franciscana's diet and potential recruits for commercial gillneting. If recruitment is affected gillnet fishing effort is likely to increase as fishers strive to mainatin catches. In turn, this will increase franciscana bycatch. Trawling operations within $3 \mathrm{~nm}$ from shore (nursery ground of sciaenids) are illegal in southern Brazil. Nonetheless, this activity takes place in large extent due to lack of policing (pers. obs.). Law enforcement with substantial penalties for offenders is strongly recommended. Reducing fishing effort could be beneficial both to franciscana and to commercially valuable depleted fish stocks.

\section{Acknowledgements}

We are indebted to Manuela Bassoi, Cristiano Dapper, Lilia and Bruna Fidelix, Andréa Adornes, Rodolfo Pinho, Marcelo Cordeiro, Lauro Barcellos (and all staff from the Museu Oceanográfico), Dani Danilewicz, Paulo Ott, Ignacio Moreno (and all GEMARS) and the fishermen from Rio Grande, Torres and Tramandaí for helping to collect data on franciscana bycatch and fishery characteristics. Lauro Barcellos and the Museu Oceanográfico "Prof. Eliézer C. Rios", in Brazil, for the long-term logistical support to the research on franciscana. To Lorenzo von Fersen (YAQU PACHA Foundation - Germany) for continuously funding the franciscana research, from which, most of the data used in the manuscript was collected. Steve Dawson, Oliver Boisseau, and Liz Slooten provided useful comments to early versions of this manuscript.

\section{References}

Bertozzi, C. and Zerbini, A.N. (2002) Incidental mortality of franciscana, Pontoporia blainvillei, in the artisanal fishery of Praia Grande, São Paulo State, Brazil. The Latin American Journal of Aquatic Mammals (Special Issue) 1: 153-160.

Bordino, P., Kraus, S., Albareda, D., Fazio, A., Palmiero, A. Mendez, M. and Botta, S. (2002) Reducing incidental mortality of franciscana dolphin (Pontoporia blainvillei) with acoustic warning devices attached to fishing nets. Marine Mammal Science 18: 833-842.

Bravington, M.V. and Bisack, K.D. (1996) Estimates of harbour porpoise bycatch in the Gulf of Maine sink gillnet fishery, 19901993. Reports of the International Whaling Commission 46: 567-574.

Brownell, R.L. Jr. and Ness, R. (1970) Preliminary notes on the biology of the franciscana, Pontoporia blainvillei, (Cetacea: Platanistidae). Pages 23-28 in Proceedings of the Sixth Annual Conference on Biological Sonar Diving Mammals - 1969, Stanford Research Institute: Menlo Park, USA.

Cappozzo, H.L., Monzón, F., Perez, J.E., Albareda, D., and Corcuera, J. (2000) Mortalidad del delfín franciscana (Pontoporia blainvillei) en la Provincia de Buenos Aires. IV Encontro para a Coordenação da Pesquisa e Conservação da Franciscana, Pontoporia blainvillei, no Atlântico Sul Ocidental, Working Paper No. 24.

Corcuera, J. (1994) Mortality of Pontoporia blainvillei in Northern Buenos Aires Province: the threat of small fishing camps. Reports of the International Whaling Commission (special issue) 15: 291-294
Corcuera, J., Monzón, F., Crespo, E.A., Aguilar, A., and Raga, J.A. (1994) Interactions between marine mammals and the coastal fisheries of Necochea and Claromecó (Buenos Aires, Argentina). Reports of the International Whaling Commission (special issue) 15: 283-290.

Corcuera, J., Monzón, F., Cornejo, I., Perez, J., Beilis, A., Gingarelli, M., Albareda, D. and Arias, A. (2000) Mortalidad de Pontoporia blainvillei en el norte de la Provincia de Buenos Aires. Pages 75-80 in UNEP/CMS (Eds) Report of the Third Workshop for Coordinated Research and Conservation of the Franciscana Dolphin (Pontoporia blainvillei) in the Southwestern Atlantic. UNEP/ CMS, Bonn, Germany.

Di Beneditto, A.P.M. (2003) Interactions between gillnet fisheries and small cetaceans in northern Rio de Janeiro, Brazil: 20012002. The Latin American Journal of Aquatic Mammals 2: 79-86.

Di Beneditto, A.P.M., Ramos, R.M.A. and Lima, N.R.W. (1998) Fishing activity in northern Rio de Janeiro State (Brazil) and its relation with small cetaceans. Brazilian Archives of Biology and Technolog 41: 296-302.

Di Beneditto, A.P.M. and Ramos, R.M.A. (2001a) Biology and conservation of the franciscana (Pontoporia blainvillei) in the north of Rio de Janeiro State, Brazil. Journal of Cetacean Research and Managemet 3: 185-192.

Di Beneditto, A.P.M. and Ramos, R.M.A. (2001b) Biologia e conservação de pequenos cetáceos no norte do estado do Rio de Janeiro. Ciências Ambientais: UENF, Campos dos Goytacazes, Brazil.

Haimovici, M., Castello, J.P., and Vooren, C.M. (1997) Fisheries. Pages 184-96 in Seeliger, U., Odebrecht, C. and Castello, J.P. (Eds) Subtropical Convergence Environments - the coasts and sea in the southwestern Atlantic. Springer-Verlag, Berlin, Germany.

Hall, M.A. (1999) Estimating the ecological impacts of fisheries: what data are needed to estimate bycatches? Pages 175-184 in Nolan, C.P. (Ed.) Proceedings of the International Conference on Integrated Fisheries Monitoring. 1-5 February Sydney, Australia. Published by FAO, Rome, Italy.

Kinas, P.G. (2002) The impact of incidental kills by gillnets on the franciscana dolphin (Pontoporia blainvillei) in southern Brazil. Bulletin Marine Science 70: 409-421.

Kinas, P.G. and Secchi, E.R. (1998) Modelling truncated data to estimate incidental kills of franciscana, Pontoporia blainvillei, by gillnets. Reports of the International Whaling Commission 48: 533-536.

Manly, B.F.J. (1997) Randomization, Bootstrap and Monte Carlo Methods in Biology. $2^{\text {nd }}$ Edition. Chapman \& Hall, London, United Kingdom.

Ott, P.H. (1998) Análise das capturas acidentais de Pontoporia blainvillei (Gervais \& D'Orbigny, 1844) (Cetacea, Pontoporiidae) nas comunidades pesqueiras do litoral Norte do Rio Grande do Sul, Sul do Brazil. Master Thesis, Pontifícia Universidade Católica do Rio Grande do Sul, Porto Alegre, Brazil.

Ott, P.H., Secchi, E.R., Moreno, I.B., Danilewicz, D., Crespo, E.A., Bordino, P., Ramos, R., Di Beneditto, A.P., Bertozzi, C., Bastida, R., Zanelatto, R., Perez, J.E. and Kinas, P.G. (2002) Report of the Working Group on Fishery Interactions. Pages 55-64 in Secchi, E.R. (Ed.) Special Issue on the Biology and Conservation of Franciscana. The Latin American Journal of Aquatic Mammals (Special Issue)1: 1-192.

Pilleri, G. (1971) On the La Plata dolphin Pontoporia blainvillei off the Uruguayan coast. Investigation Cetacea 3: 69-73.

Pinedo, M.C. (1994) Impact of incidental fishery mortality on the age structure of Pontoporia blainvillei in southern Brazil and Uruguay. Reports of the International Whaling Commission (Special Issue) 15: 261-264.

Praderi, R. (1997) Análisis comparativo de estadísticas de captura y mortalidad incidental de Pontoporia blainvillei en Uruguay durante 20 años. Pages 42-53 in Pinedo, M.C. and Barreto, A.S. (Eds) Anais do $2^{\circ}$ Encontro sobre Coordenação de Pesquisa e Manejo da Franciscana. FURG: Rio Grande, Brazil. 
Praderi, R. (2000) Estado actual de la mortalidad de franciscana en las pesquerías artesanales de Uruguay. Pages 13-15 in UNEP/CMS (Eds) Report of the Third Workshop for Coordinated Research and Conservation of the Franciscana Dolphin (Pontoporia blainvillei) in the Southwestern Atlantic'. UNEP/ CMS: Bonn, Germany.

Praderi, R., Pinedo, M.C. and Crespo, E.A. (1989) Conservation and management of Pontoporia blainvillei in Uruguay, Brazil and Argentina. Pages 52-56 in Perrin, W.F., Brownell, R.L., Kaiya, Z. and Jiankang, L. (Eds) Biology and Conservation of the River Dolphins. Occasional Papers. IUCN SSC 3: Gland, Switzerland.

Rosas, F.C.W., Monteiro Filho, E.L.A. and Oliveira, M. R. (2002) Incidental catches of franciscana (Pontoporia blainvillei) on the southern coast of São Paulo State and the coast of Paraná State, Brazil. The Latin American Journal of Aquatic Mammals (Special Issue) 1: 161-168.

Santos, M.C.O., Vicente, A.F.C., Zampirolli, E., Alvarenga, F. and Souza, S.P. (2002) Records of franciscana (Pontoporia blainvillei) from the coastal waters of São Paulo State, southeastern Brazil. The Latin American Journal of Aquatic Mammals (Special Issue) 1: 169-174.

Secchi, E.R. (1999) Taxa de crescimento potencial intrínseco de um estoque de franciscanas, Pontoporia blainvillei (Gervais $\mathcal{E}$ D'Orbigny, 1844) (Cetacea, Pontoporiidae) sob o impacto da pesca costeira de emalhe. Master Thesis, Fundação Universidade Federal do Rio Grande, Rio Grande, Brazil.

Secchi, E.R. and Wang, J.Y. (2002) Assessment of the conservation status of a franciscana (Pontoporia blainvillei) stock in the Franciscana Management Area III following the IUCN Red List process. The Latin American Journal of Aquatic Mammals (Special Issue) 1: 183-190.
Secchi, E.R. and Fletcher, D. (2004) Modelling the population growth and viability analysis for four franciscana stocks: effects of stock-specific differences in life traits, fishing bycatch, parameter uncertainty and stochasticity. Technical Paper SC/56/SM20 presented to the Scientific Committee of the International Whaling Commission. 29 June - 08 July, Sorrento, Italy.

Secchi, E.R., Zerbini, A.N., Bassoi, M., Dalla Rosa, L., Möller, L.M. and Rocha-Campos, C.C. (1997) Mortality of franciscanas, Pontoporia blainvillei, in coastal gillneting in southern Brazil: 1994-1995. Reports of the International Whaling Commission 47: 653-658.

Secchi, E.R., Danilewicz, D. and Ott, P.H. (2003a) Applying the phylogeographic concept to identify franciscana dolphin stocks: implications to meet management objectives. Journal of Cetacean Research and Management 5: 61-68.

Secchi, E.R., Ott, P.H. and Danilewicz, D.S. (2003b) Effects of fishing bycatch and conservation status of the franciscana dolphin, Pontoporia blainvillei. Pages 174-191 in Gales, N., Hindell, M. and Kirkwood, R. (Eds) Marine mammals: fisheries, tourism and management issues. CSIRO Publishing, Collingwood, Australia.

Siciliano, S. (1994) Review of small cetaceans and fishery interactions in coastal waters of Brazil. Reports of the International Whaling Commission (Special Issue) 15: 241-250.

Van Erp, I. (1969) In quest of the La Plata dolphin. Pacific Discovery 22: 18-24.

Zanelatto, R.C. (1997). Captura acidental de toninha, Pontoporia blainvillei, (Gervais \& D'Orbigni, 1844) (Cetacea, Pontoporiidae) no litoral do estado do Paraná, Brasil. Page 22-29 in Pinedo, M.C. and Barreto, A.S. (Eds). Anais do 2 Encontro sobre Coordenação de Pesquisa e Manejo da Franciscana. FURG: Rio Grande, Brazil. 